\title{
O PAPEL DAS ASSOCIAÇÕES JUVENIS NA ACULTURAÇÃO DOS JAPONESES
}

\author{
Ruth Corrêa Leite Cardoso \\ (Centro Regional de Pesquisas Educacionais de São Paulo)
}

\section{I. "Issei" e "Nissei" no Brasil}

A imigração japonêsa em nosso país tem ainda uma curta história. Iniciada no comêço dêste século (1908), não chegou a ser interrompida, apesar de ter passado por períodos de forte baixa. Ao mesmo tempo que tra estimulada pelo govêrno japonês, tinha de sujeitar-se a uma política descontínua do govêrno brasileiro, reflexo de opiniões divergentes sôbre a capacidade de assimilação do imigrante amarelo. Exemplos dessas opiniões contraditórias encontramo-las em numerosos artigos de jornais e na Revista de Imigração e Colonização publicada pelo Conselho de Imigração e Colonização ${ }^{1}$.

Dêste modo, estabelecido o critério das quotas de imigrantes de acôrdo com a porcentagem já entrada no país, o grupo japonês no Brasil nunca Se tornou muito numeroso, apesar dos estímulos que existiam no Japão a favor da emigração.

Segundo os dados do Censo de 19502 temos um total de 329.082 amarelos presentes em nossa população, e podemos aceitar êste número como representativo da situação da colônia japonêsa em nosso país, uma vez que não houve outra imigração de povos mongolóides que ultrapassasse o limite de casos esporádicos e individuais. Isto se confirma pela análise la distribuição dessa população pelas unidades da Federação 3; os Estados que receberam imigrantes japonêses são os que têm grande número de amarelos, ao passo que nos outros o total é insignificante.

Torna-se necessário lançar mão dêste recurso por não dispormos de dados que permitam agrupar nacionalidades; e mesmo que existissem, não seriam satisfatórios para os nossos fins, porque estamos interessados nos descendentes dos japonêses, que, tendo nacionalidade brasileira, não se isolam dos totais gerais dados para a população brasileira.

Os quadros que se referem à côr são, pois, os que ainda nos podem ajudar a apresentar o problema.

A distribuição do grupo de amarelos por sexo e idade (quadro 2) indica uma lenta e contínua diminuição da população nos grupos de idade mais avançada. Significa isto que não há concentração em grupos de idado madura, em que o homem tende a imigrar, mostrando que a imigração japonêsa foi fundamentalmente familial. 


\begin{tabular}{|c|c|c|}
\hline \multicolumn{3}{|c|}{$\begin{array}{l}\text { População amarela segundo sexo por unidades da Federação } \\
\qquad 1950\end{array}$} \\
\hline Unidades da Federação & homens & mulheres \\
\hline 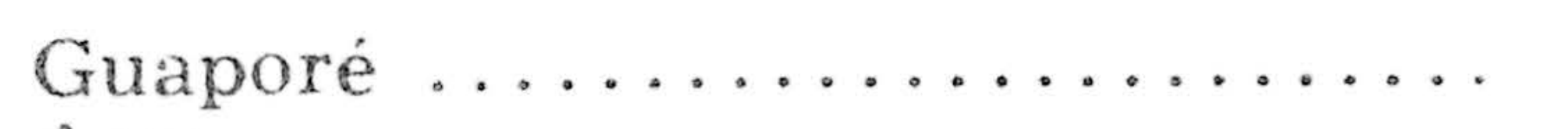 & 1 & - \\
\hline Acre $\ldots \ldots \ldots \ldots \ldots \ldots \ldots \ldots$ & 7 & 3 \\
\hline 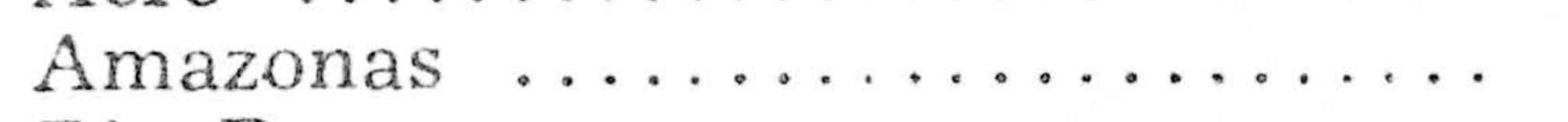 & 308 & 249 \\
\hline Rio Branco ................... & 1 & - \\
\hline 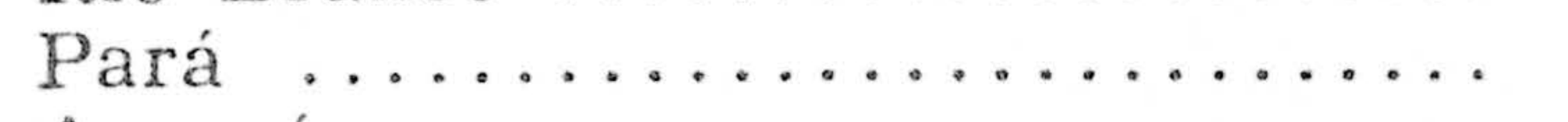 & 465 & 410 \\
\hline 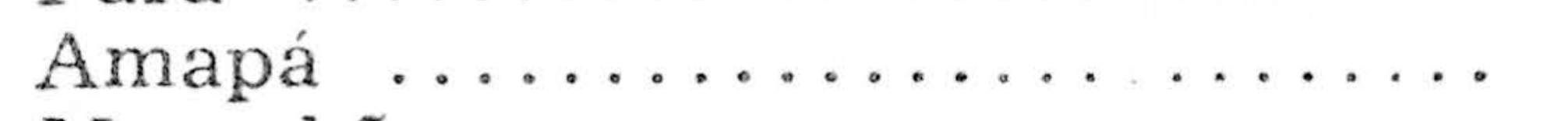 & 2 & - \\
\hline Maranhão $\ldots . . . \ldots \ldots \ldots \ldots \ldots$ & 17 & 17 \\
\hline Piauí $\ldots \ldots \ldots \ldots \ldots \ldots \ldots \ldots \ldots \ldots \ldots$ & 4 & 5 \\
\hline 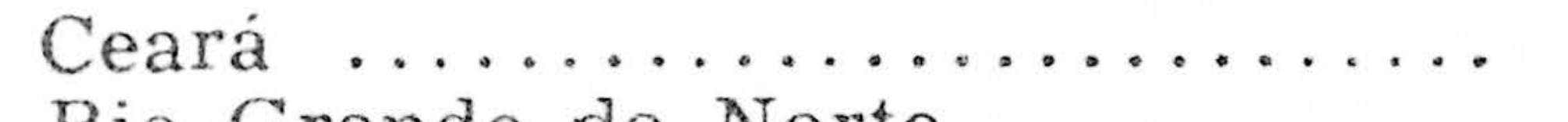 & 10 & 10 \\
\hline Rio Grande do Norte ........... & 11 & 5 \\
\hline Paraíba $\ldots \ldots \ldots \ldots \ldots \ldots \ldots$ & 22 & 24 \\
\hline 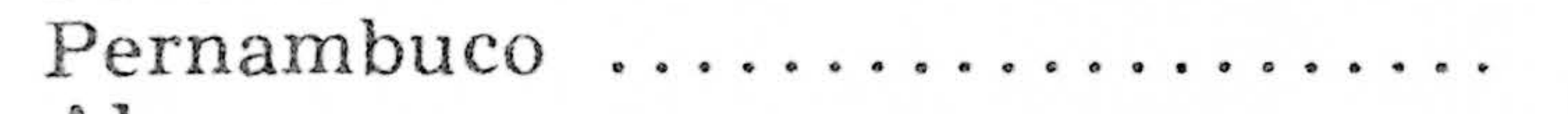 & 52 & 31 \\
\hline Alagoas $\ldots \ldots \ldots \ldots \ldots \ldots \ldots$ & 6 & 2 \\
\hline Fernando de Noronha ........... & - & -- \\
\hline Sergipe $\ldots \ldots \ldots \ldots \ldots \ldots \ldots \ldots$ & 1 & 3 \\
\hline Bahia $\ldots \ldots \ldots \ldots \ldots \ldots \ldots \ldots$ & 99 & 57 \\
\hline Minas Gerais $\ldots \ldots \ldots \ldots \ldots \ldots$ & 1226 & 1031 \\
\hline 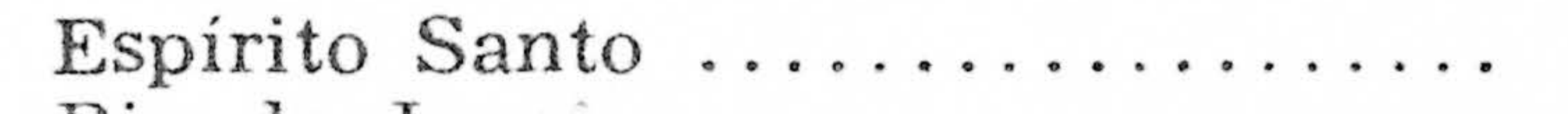 & 21 & 3 \\
\hline Rio de Janeiro $. . . . . \ldots \ldots . . .$. & 1364 & 1120 \\
\hline 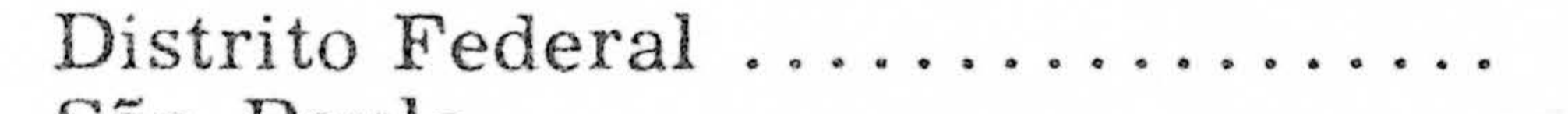 & 700 & 332 \\
\hline São Paulo $\ldots \ldots \ldots \ldots \ldots \ldots \ldots$ & 145099 & 131752 \\
\hline Paraná $\ldots \ldots \ldots \ldots \ldots \ldots \ldots \ldots$ & 20546 & 18598 \\
\hline Santa Catarina $\ldots \ldots \ldots \ldots \ldots$ & 26 & 25 \\
\hline Rio Grande do Sul ............ & 276 & 219 \\
\hline Mato Grosso $\ldots \ldots \ldots \ldots \ldots \ldots$ & 1976 & 1673 \\
\hline Goiás $\quad \ldots \ldots \ldots \ldots \ldots \ldots \ldots \ldots \ldots \ldots$ & 633 & 530 \\
\hline Total $\ldots \ldots \ldots \ldots \ldots \ldots \ldots$ & 172978 & 156104 \\
\hline
\end{tabular}

A distribuição neste grupo repete o movimento da distribuição total da população, isto é, não se trata de grupo formado principalmente por homens adultos. Podemos afirmar, e a história dos imigrantes o confirma, que os japonêses vieram para o Brasil com suas famílias, para a agrıcultura; e se localizaram em algumas regiões, onde por compra ou arrenciamento de terrenos se reuniram em núcleos de convivência, situação que, pelo relativo isolamento dêsses núcleos, facilitou a manutenção de certos padrões da cultura de origem.

Tratando-se, porém, de imigração familial, logo veio a colocar-se o froblema da educação dos descendentes, e os velhos imigrantes, "issei" na designação japonêsa, pretenderam tornar o "nissei" um herdeiro da tradiç̃̃o cultural japonêsa.

O papel da família na educação nipônica é muito importante, e à total autoridade paterna cabe formar o espírito de disciplina e obediência nos rnais jovens. Esta parte da educação foi e é cumprida pelos "issei", e para 


\section{QUADRO II}

\section{População amarela, por sexo e grupos de idade}

1950

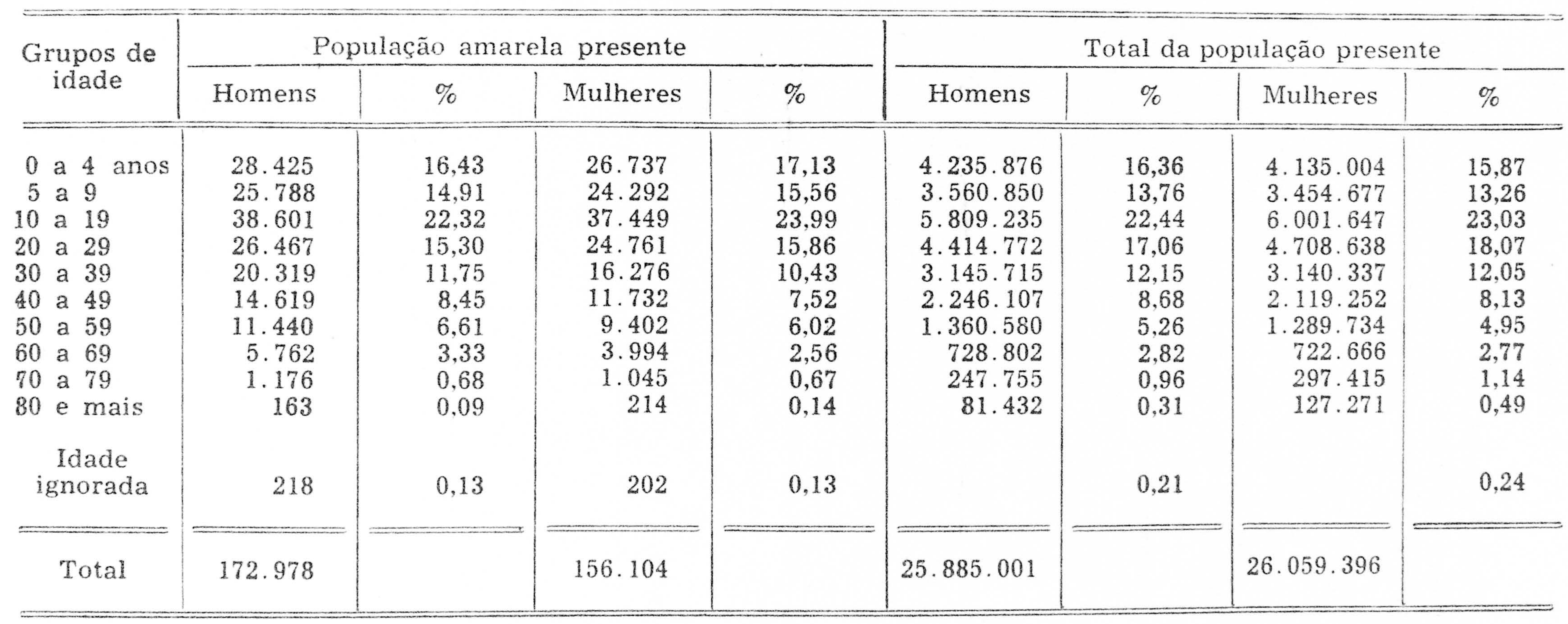


complementá-la apłreceram as escolas japonêsas, com professôres, curriculos e programas iguais aos do curso primário japonês. Antes da guerra cssas escolas funcionavam abertamente, com seus 6 anos de ensino, tanto em zonas rurais como urbanas, onde houvesse um número de japonêses suficiente para mantê-las.

A sua função principal era ensinar o japonês, informar o aluno sôbre o Japão, desenvolvendo o sentimento de patriotismo e civismo, e complementar o papel da família na imposição de uma disciplina rígida e de ima consciência de superioridade racial e cultural.

Porém, o "nissei", mais que seus pais, é obrigado a ultrapassar êste rírculo fechado de convivência, e se nas cidades consegue isto mais cêdo, através do grupo de brinquedo e vizinhança e da freqüência ao "Grupo Escolar" concomitante à da escola japonêsa, em zonas rurais mantém-se muito mais ligado à família e ao núcleo japonês, mesmo quando freqüenta o curso primário, onde aprende o português.

De qualquer forma, já bem cêdo certos problemas se colocam ao "nissei": o aprendizado do português, o ajustamento a um regime escolar diverso, a convivência com colegas e amigos. Desde então, êle começa a viver em dois ambientes distintos.

Não podemos, entretanto, caracterizar tão simplesmente a situação, admitindo dois polos opostos: a familia japonêsa e a sociedade brasileira. Nesmo dentro de sua família, encontra o "nissei" estímulos para um entrosamento no meio brasileiro, que se traduz principalmente por uma exigência de êxito profissional. Como todo imigrante, o japonês pretende uma rúpida ascensão, e espera dos filhos sucesso econômico ou adoção de uma carreira que the garanta "status" mais elevado. Esta expectativa exige um relativo entrosamento dos jovens à sociedade brasileira, levando o "issei" a aprovar e admitir um círculo de convivência, fora da familia, em que age como brasileiro.

Observa-se mesmo uma seleção intencional dos pais, escolhendo um ou alguns dos filhos para continuarem os estudos depois do curso primário e da escola japonêsa. Tal escolha é feita na base da maior vontade de estudar, do aproveitamento na escola, enquanto aos outros filhos, principalnente ao mais velho, cabe continuar os negócios da familia, e encarregarse de sua manutenção. O filho mais velho, herdeiro da autoridade paterna, deve estar muito ligado aos padrões familiais tradicionais, enquanto os outros têm oportunidade de encontrar uma profissão urbana. Essa regra não é rígida, e muitas vêzes o primogênito recebe também instrução cecolar completa, podendo então exercer uma profissão que the permita independência. O que interessa ressaltar. porém, é a dupla orientação que tem o "nissei" mesmo dentro da sua familia: pressão para tornar-se um membro da conunidade japonêsa e, ao mesmo tempo, expectativa de que através de uma formação profissional consiga ascender na escala social. 
O simples fato de existir na comunidade japonêsa a designação "nissei" para distinguir os descendentes de imigrantes, sugere que thes é atribuída uma posição particular e que não se espera necessàriamente a sua participação total na cultura japonêsa. Segundo Hiroshi Saito 4, "há mesmo certas pessoas que, sendo 'nissei', evitam o uso dêsse designativo e o fazem deliberadamente. Trata-se de uma prenoçâo que vem de longe do tempo em que a relação issei-nissei era inversa à de agora"... "O têrmo 'nissei' era, então, um sinônimo do que é 'inferior', do que é 'submisso', do que não - suro', e assim por diante". Ainda segundo êste autor. atualmente, talvez como conseqüencia da guerra, os "issei" mudaram a sua atitude, admitindo que seus filhos são brasileiros, e exigindo dêles apenas a manutenção de certos padrões japonêses. Isto corresponderia à perda da lıderança dos velhos na colônia e a crescente prestigio da geração de "nissei". "O chamado e tão debatido problema não foi, nem devia ser por sua natureza, um problema para o 'nissei', mas sim para o 'issei'. Os fatos mostram que os últimos dois lustros representam uma seqüência de recuos e revezes para a geração japonêsa. Da doutrina de 'wakoi yosai' (alma japonêsa com sabedoria ocidental) ou, mais especificamente, 'wakoi hakusai' (alma japonêsa com sabe nria orasiliana), o 'issei' passou a abraçar nova teoria: 'hakushu nitiyu' (brasileiro em primeiro lugar e japonês, em segundo plano)"...

Êste trecho mostra que no processo de aculturação dos imigrantes japonêses podemos reconhecer duas fases nítidas. A Segunda Guerra Mundial, pelos problemas que colocou, foi o marco divisor.

Os japonêses, súditos de um país do Eixo, sofreram, no período da guerra, uma série de restrições que criaram condiçóes para essa mudança de atitude. O fechamento dos jornais em lingua japonêsa colocou os imirantes num isolamento total, pois em sua maioria não conheciam o português, ficando, pois, sem noticias do desenvolvimento da guerra. Isto, aliado ao sentimento de orgulho e fidelidade que os ligava, até então, ao I ppão militarista, possibilitou o aparecimento de movimentos chamados "vitoristas", daqueles que não acreditavam na derrota do Japão.

Êsses movimentos e as perseguições sofridas durante a guerra e enquanto perdurava a crença na vitória e na fôrça do Japão, obrigaram o japonês a definir sua atitude de lealdade para com a pátria adotiva. O ciesmoronamento do Japão Imperial, guerreiro e invencivel, e a fixação cada vez maior no Brasil, onde os imigrantes conseguiam algum sucesso, foram os fatores imediatos que obrigaram a uma consciencialização da lização do "nissei" com o Brasil.

Nesta situação constituiu-se no seio da colônia japonêsa todo um gruho de esclarecidos ("derrotistas") empenhado em garantir ao "nissei" direitos que the eram negados pela autoridade paterna. O "Jornal Paulista" aparece depois da guerra (1-1-47), quando as publicações em japonès são novamente permitidas e, como representante dêsse grupo, no editorial de 
nnauguração, assim apresenta o seu programa: ". . A colonia japonêsa necessita encontrar uma diretriz acertada, baseada no conhecimento objetivo da realidade na qual se encontra. Deverá nascer daí uma nova cultura, uma nova mentalidade, coerente com o evolver da nova era. Outro problema que a colônia deve encarar com seriedade diz respeito ao nissei". O nosso futuro está intimamente ligado com o que será o nissei doravante. Nisso, o ponto essencial está em convencermo-nos de que o nissei é brasileiro. E' necessário formá-lo digno cidadão brasileiro e empenhar-se na sua completa assimilação na sociedade brasileira" ".

Estamos, pois, diante de uma situação especial, em que os imigrantes iaponêses, vivendo os problemas do após-guerra, e em sua grande maioria influenciados pelas opiniões dêsse jornal e de lideres do grupo que reuresenta tomaram consciência da marginalidade do "nissei", dai decorrendo maior tolerância com certas atitudes não conformes com os padrões tradicionais japonêses. Notamos, por exemplo, que o "issei" em São Paulo hoje não se opõe a que seus filhos freqüentem bailes em suas associaçōes, usem o português quando não estão falando com pessoas idosas, e até mesmo o namôro é tolerado. Voltaremos a tratar, mais adiante, de cono êste comportamento se impôs; aqui queremos apenas assinalar a sua Existência, e a pequena ou nenhuma reação a êle por parte do "issei". Pudemos verificar estas condições de vida familial dos japonêses através de entrevistas com "nissei" de ambos os sexos. Um índice significativo dessa tolerância é a reação do "issei" frente às associações de "nissei", pois ṫsses grêmios, promovendo bailes, oportunidades de namôro, independência das atividades dos filhos com relação aos pais, e mesmo críticas a certas atitudes dêstes, têm papel relevante na imposição dos novos padrões.

Nas entrevistas, quando o "nissei" não freqüenta associações e bailes, apresenta quase sempre razões pessoais 7 , muitas vêzes afirmando que os hais aprovariam essa forma de convivência.

Em 70 entrevistas com "nissei" matriculados em escolas secundárias cncontramos a seguinte situação quanto à reação dos pais à freqüência de associações de jovens, bailes e outras atividades recreativas:

\section{Reação dos pais à freqüência de associações}

Ṽão há oposição da família .............

Não há oposição, mas não freqüentam associações por falta de tempo ............

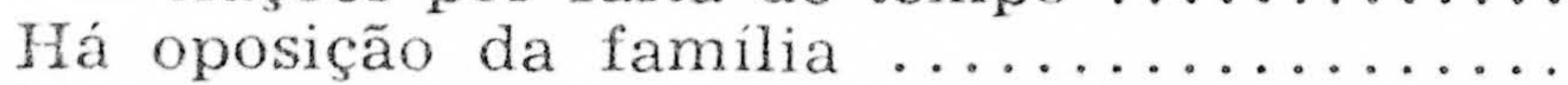

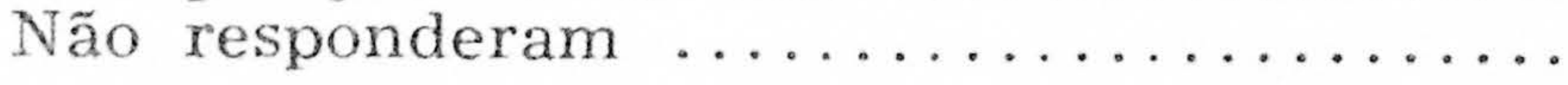

Total

Masc. Fem. Total

\begin{tabular}{rrr}
18 & 32 & 50 \\
5 & 2 & 7 \\
3 & 4 & 7 \\
1 & 5 & 6 \\
\hline 27 & $\overline{43}$ & 70
\end{tabular}

Isto significa que, de um total de 70 individuos, 57 não sentem oposição da família à freqüência às associações juvenis e casos há, mesmo 
sendo o baile a única atividade que os interessa, em que têm a anuência dos pais. Isto não é absolutamente uma situação anormal. Grande parte dos membros das agremiações não participam ativamente de sua vida, mas apenas de suas festas e reuniões importantes, isto é, naqueles momentos em que elas funcionam principalmente como impositoras de padrões ocidentais e cuase não se distinguem de outros grêmios recreativos.

A tolerância na família japonêsa, que parece ter começado depois da guerra, indica que o "nissei" não vive em dois mundos diversos, a sua familia e os grupos brasileiros que freqüenta. Profundamente atingidos peIn processo aculturativo, os padrões de comportamento familial japonêses não apresentam mais a antiga coerência; assim. os jovens ficam colocados entre dois polos de influências, que, porém, não podem ser identificados com a familia e os grupos brasileiros, representados especialmente pela єscola. como se tem pensado até agora ${ }^{8}$.

Não é só a geração de "nissei" que se vai aculturando, é um processo geral que atinge tôda a colônia, criando, por isso mesmo, condições especiais de vida para os jovens colocados entre dois mundos culturais superpostos e não paralelos.

Continuam os "issei" a pensar em têrmos da "alma nipônica" que querem transmitir aos seus filhos, mas ao mesmo tempo a ambição de êxito tconômico que trouxeram como imigrantes e a valorização das profissões liberais e das atividades intelectuais fazem dêles educadores vacilantes e não rígidos impositores das "virtudes nipônicas" como nos primórdios da imigração .

O "nissei", consciente de sua posição marginal, define-se como membro de um grupo isolado e nunca se identifica com os brasileiros ${ }^{9}$. Aceita a valorização da etiqueta japonêsa, do dominio sôbre si mesmo, da submissão aos mais velhos, e considera-se na obrigação de viver conforme estas expectativas, porque o seu próprio sucesso depende principalmente da colônia e das oportunidade que através dela the forem concedidas como profissional. O seu êxito é medido dentro e com relação à colonia japonêsa. Porém, pela sua formação e para que possa gozar de certos diseitos, deve o "nissei" viver como brasileiro, e a escola, os amigos, a sua iniciativa pessoal entre outras "virtudes ocidentais" é que the vão garantir sucesso e prestigio, mesmo dentro do grupo de imigrantes. Basta lemhrar quem são os lideres da colonia atualmente (deputados, engenheiros, advogados etc.), e a orientação do jornal de maior prestigio na colonia, o "Jornal Paulista", para vermos que isto é verdade. E' o que assinala Saito10: "Tôda essa transformação paulatina na atitude do "issei" para com 'rissei' mostra uma seqüencia de mudanças que implicou na perda de terreno para o primeiro. De fato, o chamado problema de 'nissei' traduz-se em como racionalizar o retrocesso do 'issei'."

Foi êsse crescente prestigio dos mais jovens que possibilitou o aparecimento de associaçóes juvenis independentes, que se constituiram sem a 
participação dos "issei" ou se libertaram de sua tutela, para defender e dar prestígio ao "nissei", reunindo todo um grupo com os mesmos problemas e as mesmas necessidades.

\section{Associações de "nissei"}

Sob a rubrica associação de "nissei" reuniremos clubes e grêmios bastante diversos quanto a sua finalidade, mas que agrupam os jovens "nissei" em atividades organizadas, propiciando a convivéncia.

Verificarnos que existe um grande número de clubes recreativos e esportivos, organizados e freqüentados por jovens descendentes de japonêses. Academias de judô, grupos de pingue-pongue, times de basebol, congre\&ações religiosas e associaçoes culturais são formas que essas agremiações étnicas comumente assumem. A explicação do grande número de associaçoes em relação à população de "nissei" pode ser procurada nos incentivos merentes à cultura japonêsa. Tradicionalmente os japonêses se organizam $€ m$ agrupamentos por idade, com funções definidas, e os "seinen-kai" ou "seinen-dan" (agremiação de jovens) foram reorganizados modernamente e aproveitados para a politica nacional e militarista dos governos contemporâneos. Êste fato é assinalado para o Japão por Stoetzel, na seguinte passagem: "Traditionellement, les jeunes japonais sont groupés en orgarisations qui leur sont propres. Si les administrations autoritaires, à l'époque contemporaine, ont ranimé, renforcé et réorganisé dans un esprit national ces associations de jeunes, elles ne les ont nullement créées et n'ont fait au contraire que tirer parti d'un trait culturel très ancien et curable de la société japonaise" 11.

A imigração japonêsa no Brasil data dêste século, e os imigrantes, irazendo do Japão de pré-guerra aquêle espírito militarista, valorizavam as associações juvenis a tal ponto que elas apareceram em número bem maior que as associações de senhoras, de velhos, de meninos etc., que também existiam tradicionalmente e que, por sua vez, começaram a surgir no Brasil. Entretanto, se o "seinen-kai" conseguiu viver e espalhar-se por tôdas as zonas de população japonêsa, foi não só porque os "issei" o desejavam, mas também porque se tornaram recursos de integração do "nissei" à sociedade brasileira, adquirindo assim função diversa da original. Daí o número de associaçóes que existem hoje e que, apesar da diversidate de fins, reunem sempre uma população exclusivamente "nissei", que cnfrenta problemas comuns. Oferecem soluções aceitas pelo "issei" e pelo "nissei" quanto às formas de recreação, liderança e atividades culturais dos jovens.

Estamos muito longe de ter uma relação completa das associações existentes em São Paulo, cidade a que limitamos a nossa pesquisa. A lista que temos foi levantada através de entrevistas e consultas ao Jornal Paulista, e se certamente abrange as maiores e mais freqüentadas, deixa de lado 
muitos grupos da periferia, que só um contacto mais prolongado permitiria localizar, porque geralmente reunem os adolescentes de um núcleo de vizinhança, ocupando alguma residência particular para as suas atividades.

E' preciso distinguir entre êstes dois tipos de associação: o "clube" recreativo-cultural ou esportivo, corn sede central e número grande de sócios, em geral bastante conhecido na colônia, e os pequenos grêmios em grande parte suburbanos que congregam um grupo de vizinhos, sendo em geral controlados pelos "issei". Êsses pequenos grupos são representativos de áreas de população japonêsa, enquanto os "clubes" maiores, reunindo jovens de tôda a cidade de São Paulo, e recém-vindos do interior, têm um quadro social bastante diversificado e não se ligam a uma área delimitada. Funcionam como grupos de idade que procuram a integração do "nissei", permitindo selecionar e impor certos comportamentos novos.

O fato de essas associações juvenis terem fôrça para impor atitudes e comportamentos novos só o podemos compreender depois de conhecer o seu desenvolvimento.

Sabendo que o "seinen-kai", isto é, a forma tradicional de associação de jovens japonêses, aparece patrocinado pelos "issei" e diretamente controlado por êles, podemos avaliar o prestígio que gozava na colônia, e o inierêsse dos pais pelas atividades que seus filhos desenvolviam nesses núcleos.

Porém, como já foi assinalado, a Segunda Guerra Mundial foi um marco importante para a mudança de atitude dos japonêses, pois com as restrições a reuniões e a consciência da discriminação agora quase legalizada, muitas alterações foram ocorrendo naquelas instituições.

O "seinen-kai" foi se libertando da tutela do "issei". Seus diretores só podiam ser brasileiros; e os filhos de imigrantes, diante do impacto da declaração de guerra ao Japão, tomaram consciência de sua situação particular em razão de sua nacionalidade brasileira, atuando decididamente na direção dos clubes. O "nissei" pôde dar-lhe outra orientação, de certa forma atualizando as suas atividades.

Afastados os velhos "issei" dos conselhos e das diretorias, os "seineniai" enfrentaram um problema de sobrevivência, porque não tinham meios para resolver suas necessidades econômicas. E a sua independência só foi possível na medida em que certas atividades novas se foram desenvolvendo, tais como bailes, concursos de beleza, jogos de futebol ou basebol, que pudessem oferecer alguma renda. Ainda hoje estas atividades são importantíssimas para a manutenção dêsses clubes, apesar de contarem sempre com a ajuda dos "issei" esclarecidos.

Conseguida esta independência econômica e enfraquecida a domina"ão dos "issei", os "nissei" transformaram os "seinen-kan" em clubes recreativos capazes de atender à segunda geração de japonêses num momento em que a consciência de uma definição de nacionalidade se impunha.

Tal é, em traços gerais, a história de quase tôdas as atuais associações de São Paulo. Representa bem a transição das relações "issei"-"nissei", 
dando ao último um crédito de confiança. E por que the foi concedido êste crédito? O entrosamento do "nissei" à vida urbana exige dêle um grande esforço, porque o adolescente recém-saido de uma familia de camponeses tradicionais e herdeiro de padrões culturais estranhos, deve vencer muitas barreiras até que possa ajustar-se convenientemente a certas condicôes rotineiras da vida urbana. A família japonêsa, oferecendo, como já vimos, alguns incentivos ao ajustamento, falha como agente integrador; o agrupamento de jovens passa a exercer esta função, reunindo a geração afligida por problemas comuns e tentando oferecer soluções. Com a sua iransformação funcional, o "seinen-kai" tornou-se uma instituição capaz de responder às necessidades de integração dos jovens "nissei" à sociedade mais ampla.

O êxito profissional dos jovens, que é uma meta na educação familiar do "nissei", depende desta integração aos ideais de comportamento da sociedade brasileira; para possibilitá-la, as associações oferecem aos "nissei" uportunidades para se adaptarem a seus papéis ocidentais.

Segundo Eisenstadt 12 , os grupos de idade aparecem em sociedades em que a família não constitui a unidade principal da divisão social e econômica do trabalho, e onde o individuo deve aprender papéis não ensinados pela família. Pode-se dizer, segundo êste autor, que os grupos de idade constituem uma esfera de conexão entre a família e outras esferas institucionalizadas da sociedade. Para o nosso caso, a análise de Eisenstadt é bastante explicativa, mostrando bem a posição das associações juvenis na situação de contacto observada em São Paulo. A família patriarcal japonêsa está se dissolvendo como unidade econômica, sob a pressão do processo de urbanização e da preocupação de ascensão social decorrente da situaçâo de imigrantes. Os filhos procuram uma profissão urbana ou tornamse donos de pequenas propriedades agrícolas, onde residem e constituem familia, desligando-se do núcleo familial. Por isso, a continuidade dêste c’mo unidade econômica, está em perigo. Por outro lado, o grupo familial não é capaz de preparar os filhos para os papéis que terão de desempenhar como adultos. A família deseja e incentiva a procura de uma profissão urbana, mas não pode preparar a integração dos jovens à sociedade brasileira, condição necessária ao êxito.

Tal situação cria para as associações uma função específica: abrasileirar o "nissei", fornecendo-lhe pelo menos padrões de comportamento adequados. E' desta maneira que estão agindo os "clubes", permitindo e valorizando condutas outrora vedadas ao "nissei", tais como: dançar, participar de festas ocidentais, concursos de beleza etc. E, mais ainda, dando-lhe um núcleo de convivência em que se usa apenas a língua portuछuêsa, cujo domínio é condição importante para o suresso nos cursos escolares e na vida profissional.

Atualmente, tôdas as associações de "nissei" atuam desta maneira, e presenciamos um processo de aglutinação dos pequenos clubes para for- 
mar outros maiores. E' o caso da atual Associação Recreativa e Esportiva Lux, conhecida como sociedade Arelux. Nasceu há 5 anos, no bairro de Monções, organizada como um "seinen-kai", e congregando principalmento jovens recém-vindos do interior, que, sentindo-se isolados e com dificuldades para participar de atividades recreativas e esportivas em clubes nacionais, fundaram essa agremiação. Posteriormente a sociedade cresceu e mudou de orientação, passando a chamar-se Associação dos Nisseis de São Paulo, graças à participação ativa de um grupo esclarecido que pretendia maior autonomia, para que o clube pudesse realizar bailes e ouiras atividades condenadas pelo grupo dos velhos. Incorporou o Noroeste, time de futebol que existia isolado, e posteriormente criou-se o departamento de basebol e o de pingue-pongue. Em meados de 1957, fundiu-se com c grêmio King, formando então a Arelux, que publica um jornal, cujos objetivos vêm expostos no primeiro número: "Além de informar, êste boletim mensal procurará, dentro do elevado espírito que norteiam os nossos propósitos, orientar, educar e também criticar. Sim, criticar, porque através de uma crítica consciente e construtiva é que se orienta e se educa" 13.

A história da formação da Arelux não é única. Muitos grupos de basebol, times isolados de futebol, grêmios onde se joga pingue-pongue, pequenos pontos de reunião de jovens, estão se fundindo para formar clubes maiores, mais sólidos e independentes econômicamente, com maior prestıgio, e por isso mesmo capazes de influência mais eficaz sôbre o "nissei" e o "issei".

Em tôdas as associações encontramos uma consciência muito clara da posição do "nissei" e da necessidade de educá-lo, de torná-lo capaz da convivência com brasileiros. Principalmente os diretores têm opiniões formadas sôbre o assunto e pretendem que os "clubes" são uma ponte que permite posteriormente a participação do "nissei" em outros clubes nacionais 14 .

Dentro da colônia japonêsa, já se esboçou uma crítica a esta tendência. A página em português do Jornal Paulista foi o veículo dessas opiniões, que muitas vêzes apareceram em artigos violentos. Afirmam os redatores dessa página que as associações são órgãos segregativos, que, isolando o "nissei", permitem que êle mantenha certas ligações com a colônia movido por possiveis vantagens politicas ou profissionais. Insistem os críticos em que o filho de japonêses é brasileiro e deve agir sempre como tal, vivendo os problemas nacionais, e não limitar-se aos da colônia. Tal atitude é coerente com o edital de inauguração daquele jornal e com a linha que mantém, pelo menos na página em português. Ai encontramos trechos veementes contra as associações de jovens, tais como êste: "Quando o Jornal Paulista combate os 'clubecos de nisseis', fá-lo conhecendo e prevendo as conseqüências dêsse isolamento. E creio mesmo que êsses clubes, no final das contas, não passarão de clunâmbulos a arrastarem-se pelo campo irreal de uma suposta irrealidade frustrada" 15. 
Us redatores desta parte em português do jornal mantém ainda esta posição extremada. Chegaram mesmo a realizar mesas-redondas com os aretores de clubes, defendendo a idéia de sua extinção ou transformação, para que o "nissei" enfrente o convivio com os brasileiros em lugar de se isolar.

$\mathrm{Na}$ verdade, todos os clubes desejam manter-se como grupo isolado, e rlesejam a participação apenas de "nissei" 16. Encontram para esta situação justificativas várias; mas, na verdade, o prestigio da associação aos olhos do "issei" estaria em perigo se ela fôsse mais aberta. O seu trabalho de abrasileirar o "nissei" só é possivel se contar com a aprovação dos "issei", e. como já vimos atrás, esta aprovação existe atualmente.

Por outro lado, os lideres dos jovens não perderam ainda de vista a colonia japonêsa, e tôda a sua ação tem em mira o seu grupo de origem e não a sociedade mais ampla. Em uma mesa-redonda sôbre o assunto, ouvimos, de diretores de clubes, frases como estas: "Quando entrei para o Clube $\mathrm{X}$, eu era contrário a esta associação, achei que deveríamos entrar de peito aberto num clube brasileiro, mas pensei se seria justo deixar de lado os milhares de "nissei" que existem no campo e recebem educação meio japonêsa, meio brasileira? Então entrei para o clube, para melhorar tsta situação". Ou ainda outra opinião: "Dizer que os clubes X ou Y provocam segregação racial, posso aceitar, mas não vejo por que condenar. Depende da finalidade: o clube $X$, com caravanas e competições, procura elevar o nível dos japonêses." Isto mostra claramente que nas associações o "nissei" encontra um grupo homogêneo de convivência, que permite o aprendizado, com um mínimo de conflitos, de certos comportamentos que a família, pelas razões já apontadas, não the pode ensinar. Realmente, as associações selecionaram alguns focos de atuação tais como impor o baile como recreação admissível, o uso do português, o namôro e o casamento não arranjado, discutindo êstes assuntos e, principalmente, criando condições para que isto se realize normalmente.

A mentalidade feminina e as relações dentro da família são, por seu turno, objeto de constantes discussões com os "issei". A êste respeito são muito esclarecedores os relatórios das "caravanas culturais" realizadas por um dos "clubes"; através dos resumos das discussões travadas no interior com o "issei" bem se percebe a posição de luta contra certos padrões de comportamento e uma atitude de tolerância para com outros. As referidas caravanas, tidas como a realização máxima daquele "clube", demonstram claramente como os seus dirigentes vêem o problema: é preciso mudar a mentalidade dos velhos japonêses, introduzindo comportamentos novos, para que a colônia ganhe mais valor aos olhos dos brasileiros e não seja ridicularizada por atitudes estranhas. E' manifestação de lealdade para com es outros "nissei", uma consciência de responsabilidade que se traduz em constante preocupação com a ascensão social do grupo. Na introdução ao relatório da VII caravana cultural encontramos êste trecho: "Comprome- 
temo-nos intimamente, desde que estivesse ao nosso alcance, fazer algo de proveitoso, seja estimular aos estudos, logo combatendo a ignorância que mina o espírito de nossos irmãos do 'hinterland', principalmente da zona rural, prontificando-nos a auxiliá-los em qualquer eventualidade, seja pela apresentação de meios para melhorar a cultura através da boa leitura, rádio etc.; seja ainda prevenindo os pais do perigo futuro de uma escolha errada da vocação de seus filhos, os cuidados que se devem tomar na educação dos mesmos, física e moralmente; seja também demonstrando a necessidade de zelar pelo bem-estar do nosso organismo, quer dos dentes, quer das doenças mais comuns naquela região" 17.

Por ai se vê como pretendem agir êsses jovens "nissei". O problema da ascensão social é para êles muito importante, e através da convivência €m clubes transmitem não somente padrốes ocidentais indispensáveis à elevação de "status", mas procuram também influir diretamente sôbre as familias, usando o prestígio da associação para conseguir a mudança de certas atitudes dos camponeses imigrantes que possam comprometer seus filhos aos olhos dos brasileiros.

Tais preocupações são muito claras no clube que realiza as caravanas para o interior, tendo como associados só estudantes, principalmente universitários; mas existem também em associações de quadro social diferente.

Perguntando a um membro da diretoria de um clube por que êle, que, tendo vivido em cidades grandes, tinha facilidade em conviver com os brasileiros, não procurava freqüentar um clube nacional, recebemos como resposta: "Isto é um problema econômico, porque o Paulistano e o Harmonia exigem Cr\$ 50.000,00 de jóia".

De modo geral registra-se a procura de participação em ambientes considerados de classe alta. Como existem muitas barreiras para esta participação, a solução é segregação em sociedades capazes de atuar junto à rolônia no sentido de elevar o seu nível, ensinando e exigindo tudo o que parece sinal de status elevado. Esta preocupação encontramo-la também num clube de tipo diferente, que congrega filhos de lavradores e visa a difundir entre os homens do campo técnicas de trabalho mais produtivas e aumentar o nivel de confôrto e higiene. Embora organizado segundo os moldes americanos, e até mesmo usando nome americano, êsse clube nasceu da iniciativa de japonêses e seus descendentes, dirigindo-se apenas à colônia. Em princípios de 1957 assistimos a uma concentração de jovens lavradores em que 80 filhos de japonêses de ambos os sexos receberam aulas sôbre técnicas agricolas, métodos modernos de criação, medidas higiênicas, música e arte, além de informações de caráter geral. O clube reúne principalmente "nissei". No jornal que publica encontramos trechos que indicam claramente a preocupação de elevar o nivel de vida no campo através dos jovens, dos quais se espera, aliás, que se empenhem pela reeducação dos pais. Lê-se ai, por exemplo: "Voltamos à casa do senhor M., e, to. 
mando chá, começo a ouvir as conversas do jovem N. N., que vai contando as condições de agricultura da região. Êle já tem o modo de pensar diferente dos pais japonêses. Êle é brasileiro e moço do trabalho agrícola. Conhece o assunto com que trabalha..."1s.

Condição preliminar para a melhoria de condições de vida é um sentimento de ligação à terra. Daí o esfôrço de dar ao "nissei" consciência de cue "é preciso agir como brasileiro. Os moços de Salvação preferem conversar mais em japonês do que em português. A terra, entretanto, que os acolhe é o Brasil, onde todos falam a lingua portuguêsa. A lingua portuguêsa deve ser estudada com muito carinho"19.

Em resumo: as associações se caracterizam pela preocupação contínua em criar condições para a ascensão social do "nissei", i. é, fornecendo-lhe comportamentos e atitudes que the permitam conseguir o êxito esperado pela familia.

Porém, nesse abrasileiramento aparente do "nissei" não se pretende cortar as ligações dêste com a colônia, mas aumentar o prestígio dêle aos "Whos dos "issei", com vistas a maiores facilidades para a vida profissional. Em geral, os profissionais liberais começam suas atividades em firmas de japonêses ou contando com clientela certa na colonia. Mesmo os que conseguiram um desligamento bastante grande começaram a vida profissional com a vantagem de contar com um grupo solidário.

E' nesse ponto de convergência que se colocam as associações, completando a ação da família, algumas vêzes mesmo entrando em luta com os "issei" menos "esclarecidos", mas tendo sempre em mira o grupo de imigrantes e tôda a ação voltada para êle.

\section{A associação de jovens e a formação da opinião}

Pensar o "nissei" de São Paulo como uma unidade é grande êrro. Estamos diante de adolescentes com as mais diversas histórias de vida: alguns que vêm do campo, depois de passarem com a família por duros períodos de ajustamento, outros criados em grandes cidades, filhos de pequenos comerciantes, sempre em escolas brasileiras, com cinema, rádio $€$ tc. ao seu alcance. Evidentemente a diversidade de condições faz com cue reajam de modo diferente às mesmas situações. O clube juvenil procura homogenizar algumas atitudes e formas de comportamento. Desde o início não há uma distinção rigorosa das condições de vida, correspondente a uma distinção entre os jovens vindos do interior e os nascidos na capital. As entrevistas com alunos das escolas secundárias mostram que mesmo na periferia de São Paulo existem condições de vida rural, e é grande - número de alunos que moram em chácaras, onde trabalham com a familia. Essses, quando freqüentam "clubes", o fazem aos domingos em pequenas agremiações de bairro, quase sempre do tipo "seinen-kai", escapando assim à influência das associações maiores e centrais, e ficando bastante mais ligados à autoridade e às opiniões dos pais. 
Temos entrevistas com alunos filhos de lavradores, que, vivendo em pequenos núcleos de granjas, conservam um tipo de vida quase rural. Todos êsses entrevistados, embora nascidos em São Paulo, vivem isolados da cidade.

Entre os "nissei" que vêm do interior é que parece haver os com maior potencialidade para se urbanizarem e com maior consciência dos problemas de contacto, porque o jovem que migra sòzinho, devendo enfrentar a cidade grande e ajustar-se a ela, sente melhor os obstáculos decorrentes de sua condição de "nissei".

E é aí que desenvolve atitudes de lealdade para com o grupo de origem, ao mesmo tempo que é obrigado a uma revisão de certos comportamentos, que deverão ser abandonados. Note-se que os diretores das associaçôes são, em sua maioria, escolhidos entre os que vieram para São Paulo adolescentes para freqüentar cursos superiores ou preparar-se para isto.

A história de um estudante de engenharia que veio de uma cidade onde viveu sempre entre brasileiros é bem significativa: "Vim para São F́aulo fazer o $3 .^{\circ}$ ano científico e o cursinho, e quando entrei para a Politécnica é que comecei a freqüientar o clube $\mathrm{X}$. Aí senti a responsabilidade para com os "nissei", e se eu poderia viver fàcilmente no meio brasileiro, porque sempre vivi e falo bem português, outros não podem e por isso resolvi participar do clube. Enquanto estive em Bauru só tive uma namorada "nissei", e agora não me casarei com brasileira, porque já não acho que o casamento é só entre os dois esposos. Atualmente estou aprendendo japonês, e me arrependo de não o ter aprendido quando pequeno, porque pode ser muito útil". Êste trecho de entrevista mostra duas coisas: $\left.1 .^{\circ}\right)$ a mudança de atitudes a partir das necessidades criadas pela vida em São Paulo; e 2. ) o papel do clube na formação de opiniões e na valorização de certos aspectos da conduta ligados à colônias japonêsa, tais como a língua, o respeito à familia etc.

Partindo dêstes dados, vemos que o clube de "nissei" não é dirigido aos "nissei" do interior, mas feito por êles. Êsses jovens é que por suas experiências sentem necessidade do ambiente restrito do clube, em que se vão recolocar problemas e formar opiniões, chegando em alguns casos a ir mais longe que seus companheiros nascidos e criados na capital. Tomando, por exemplo, a opinião de 70 escolares "nissei" sôbre o casamento misto, observamos que $44,8 \%$ dos 49 nascidos em São Paulo ou vindos com menos de 10 anos aprovam o casamento misto e justificam-no pelos entendimentos entre os cônjuges, isolando, portanto, a família do contrato de matrimônio; e se tomamos os estudantes vindos com mais de 10 anos para São Paulo e os que aqui estão sem as familias, num total de 21 entrevistas, temos $61,9 \%$ que se manifestaram a favor do casamento fora da colônia. Êste é apenas um exemplo de que as experiências de ajustamento por que passa o "nissei" ao se transferir para a cidade criam condições para uma revisão de suas opiniões. E tomamos o tópico casamento 
misto porque as respostas são indicativas de tôda uma situação, pois a admissão do casamento misto implica novas relações familiares, em que a submissão à vontade paterna está ausente, e todo o sistema tradicional do casamento arranjado cai por terra.

E' bem verdade que, em grande parte, os alunos entrevistados aprovam o casamento misto, mas não para si mesmos, isto é, não enfrentariam a sua familia tentando quebrar os padrões tradicionais. Mas a importância dessa opinião está mais no fato de ser uma nova racionalização da situação de contacto, em que os limites da colônia não são os da convivên$\mathrm{cia}^{20}$. Todos os diretores de associações que entrevistamos afirmavam categòricamente sua opinião favorável ao casamento misto, mas nenhum procuraria para si tal situação. Apesar disto, muitos são os dados que nos permitem afirmar a clara posição das associações como grupo de defesa do casamento misto 21 contra a intransigência dos "issei" que näo querem abrir mão do sistema tradicional de arranjar casamento e não admitem ainda a convivência em família com pessoas de outra origem. Porém esta defesa é sempre feita em têrmos da liberdade de escolha do cônjuge, contra o casamento arranjado sem a participação dos jovens. Êste padrão já não se pode manter, dada a atual situação de vida do "nissei", que já tem como ideal o casamento romântico, na base de um entendimento entre os cônjuges. Porém, para lutar contra o padrão tradicional, é preciso que os "nissei" admitam a livre escolha do cônjuge, e não podem restringí-la ao grupo de japonêses e seus descendentes.

A admissão do casamento na base do entendimento entre os cônjuges im põe de imediato uma série de inovações para os "nissei", tais como o namôro como padrão reconhecido, a aceitação do casamento misto, a admissão de convivência entre jovens dos dois sexos. As associaçôes, através de suas atividades, propiciam ocasiões para que tais padrões tenham vigor; e assim é que pouco a pouco conseguiram impor o baile como forma de recreação apesar da resistência dos "issei", que, presos às suas tradiçies culturais (casamento arranjado e não-convivência entre os sexos), não podiam compreendê-lo 22 .

Encontramos, pois, atualmente, uma situação especial, em que os jovens, premidos pela necessidade de ajustamento a uma nova categoria de idade, procuram as associações para aí reorganizar suas opiniões, e, a partir de certos comportamentos que a situação de vida urbana exige, são obrigados a admitir como válidos muitos outros que não estão dispostos a aceitar para si. De qualquer maneira, isto impede que continuem a existir, ao menos como padrão ideal, restrições a casais em que um dos cônjuges não é japonês ou descendente de japonêses, o que facilitará êste tipo de casamento.

E' interessante assinalar o mecanismo de imposição dessas opiniões, porque tôda a preocupação dos jovens dirigentes dos clubes é dirigir-se aos "issei" e manter aos olhos dêstes uma posiçâo de prestígio. Assim os 
adolescentes não quebram abertamente a atitude de respeito aos pais, e sem luta, porque não se dispõem a pôr em prática as opiniões que discutem, é muito mais fácil impor sua aceitação.

Para compreender isto, basta lembrar as relações tradicionais na fanilia japonêsa e suas transformações com o crescente prestigio dos "nissei", que ganharam fôrça diante dos velhos sem quebrar a sua autoridade. Fm nossas entrevistas, observamos que a obediência aos pais e irmãos mais velhos ainda vigora, e freqüentemente obtivemos respostas assim: "Nunca discuto com meus pais por qualquer motivo", mas esta submissão não é total, e os "issei" estão prontos a aceitar inovações, desde que confiem nos jovens.

Compreendemos, então, por que é grande o número de "issei" nas conferências ou mesas-redondas patrocinadas por clubes de jovens. São sempre êles que mais discutem e demonstram interêsse, encarando com grande seriedade estas iniciativas dos "nissei". Por sua vez, os jovens muitas vêzes lamentam o desaparecimento crescente da obediência aos mais veIhos, louvando-a como costume dos mais belos da família japonêsa.

Parece-nos que tal situação se tornou possivel porque os primeiros imigrantes realizaram uma rápida acomodação, o que permitiu ao "nissei" quase manter o mesmo padrão. A atitude de aceitação, desenvolvida desde os primeiros esforços de ajustamento a uma cultura muito diversa, e aumentada depois da guerra, pela situação particular vivida pelos imigrantes, faz com que os jovens encontrem campo propício para discussão e conseqüente aceitação daqueles comportamentos novos que sentem necessários. Por sua vez, os "nissei" não precisam quebrar uma grande resistência, podem manter quase as mesmas relações dentro da familia, apesar de estarem atuando decididamente para a mudança de certos padrões.

Se quiséssemos procurar o sentido desta atuação, veríamos que o que se procura é a crescente ocidentalização da colônia. Tudo o que diverge muito dos padrões ocidentais constitui problema para o "nissei" e todos os assuntos que discutem, e as idéias que pretendem impor sôbre: higiene, mentalidade feminina, elevar o grau de instrução etc., demonstram essa procura e valorização da ocidentalização, e isto se liga à preocupação de ascensão social que domina os jovens. Para conseguir a ascensão se reunem em clubes, onde podem agir segundo os padróes ocidentais, que identificam com os de classe alta; mas sabem que a família pode ser um empecilho, mantendo costumes que lembram sua condição de imigrantes e podem ser identificados como típicos de classe baixa; por isso têm sempre em vista a colonia, e a pretensão de modificá-la.

Para compreendermos bem a tentativa de ascensão em todos os seus aspectos, seria necessário verificar o significado dos traços raciais nesse processo. Infelizmente ainda não temos dados para discutir mais pormenorizadamente o problema, mas pudemos perceber que os japonêses têm lima clara consciência de sua superioridade racial, mito que decorre da 
educação militarista recebida no Japão. Isto leva fàcilmente ao isolamento e à segregação; e somando-se os obstáculos que se apresentam ao "nissei" quando êste pretende um contacto mais aberto com os brasileiros, compreendemos a facilidade com que se isolam nessas sociedades e por que, na verdade, há pouca vontade de quebrar o isolamento. O "nissei" ainda se pensa como um membro da colônia japonêsa, consciente de seus limites e de sua superioridade racial, e não sente as barreiras que existem à miscigenação, porque êle próprio não deseja quebrá-las.

Pretendemos obter mais dados para tratar amplamente dêste problema, de importância capital para se perceber o mecanismo de ascensão social dos "nissei", mas por ora temos que nos limitar a indicá-lo.

\section{Conclusões}

Retomando as hipóteses enunciadas em nosso "Projeto de pesquisa", rrecisamos colocá-las em outros têrmos, de acôrdo com os dados colhidos.

Aceitamos, como ponto de partida, uma estreita ligação entre as associações juvenis e a área em que se localizam, admitindo que são representativas do núcleo de que são partes. Procurávamos ainda classificá-las de acôrdo com opiniões expressas por seus membros, pretendendo medir uma atitude de resistência ou aceitação do processo aculturativo que atinge a colônia japonêsa. Verificamos, porém, no decorrer da pesquisa, que a situação real é bem mais complexa.

E' verdade que as associações de "nissei" aparecem freqüentemente em áreas de concentração de população japonêsa, mas isto não significa que seu público se limite a esta população. Como foi visto atrás, devemos distinguir entre associações do tipo "seinen-kai", criadas e dirigidas por um pequeno núcleo de vizinhança, e outras, localizadas mais próximas do centro da cidade, dirigidas e organizadas por "nissei" e cujo público é diverso e heterogêneo. Ao segundo tipo pertencem as que mais nos interessaram, por terem atuação direta na imposição de novos padrões e na homogenização das opiniões do grupo que abrangem.

Não podemos, pois, procurar ligar simplesmente um "clube" ao bairro em que êle se localiza, mas é preciso procurar sua diversificação interna. Não há "clubes" de um e outro tipo que reùnam só "nissei" de um bairro, ou só jovens vindos de zonas rurais. Em todos êles encontramos uma população bastante diversificada quanto à zona de origem, porém mais homogênea quanto à posição social.

Como são associações juvenis, é difícil afirmar que exista uma seleção social consciente, uma vez que os jovens ainda não têm definida a sua posição na sociedade. Porém, todos êles têm bem presentes certas perspectıvas de ascensão social. E' bom lembrar que, como filhos de imigrantes, a aquisição de uma profissão urbana e socialmente valorizada é a meta de todos êstes adolescentes se o seu agrupamento se faz em têrmos das suas 
perspectivas de ascensão social. Isto fica bastante claro nos casos de grêmios só de universitários, ou de lavradores que pretendem melhoria técnica, mas mesmo nos outros clubes notamos uma relativa homogeneidade ce aspirações e perspectivas.

Muitas associações e times esportivos nasceram da necessidade de se manterem reunidos jovens vindos de uma mesma região. Estudantes, longe de suas famílias e isolados em uma cidade grande, organizavam uma atividade qualquer, freqüentemente um time de basebol ou futebol, para manter um núcleo de recreação e convivência. Nos bairros onde há concentração de japonêses, também apareceram e aparecem pontos de reunião que acabam por se formalizar e dar origem a uma associação; isto, porém, acontece, concomitantemente com o aumento de freqüentadores, o que alarga a área de ação do grêmio, passando então a agir imediatamente a seleção dos associados pela avaliação de sua posição social.

Sôbre êste assunto continuamos recolhendo dados que possibilitem tratar mais amplamente o problema.

Quanto à outra hipótese levantada, que diz respeito à classificação das associações de acôrdo com sua atuação em face das mudanças impostas peIa marcha da aculturação, procuramos mostrar como apenas certas opiniões, e sempre as mesmas, são discutidas pelos "nissei", e a repercussão que alcançam dentro da colônia.

Isto mostra que os problemas são os mesmos. e os focos de atuação de todos os grupos são comuns, apenas as maneiras de discutir e impor comportamentos novos variam de clube para clube.

Atualmente a associação de "nissei" aparece, pois, com função clara, criando condições para a aceitação de comportamentos novos, e mantendo a ligação do jovem à colônia através da preocupação de agir no sentido da ocidentalização e da procura de ascensão. Não se pode esquecer, porém, que êsses grêmios recreativos são núcleos de segregação. Aí só convivem "nissei", impedindo um maior contacto dêstes com jovens de outras crigens. Procuramos no decorrer do trabalho apontar as razões disto e devemos indicar que se essa forma de segregação permite à associação se» um agente positivo de aculturação, ela se cria depois que o adolescente, passando por experiências críticas de ajustamento à vida urbana, sente necessidade de um isolamento para refazer suas opiniões e torná-las vigentes. Compreendida assim a ação dos jovens, vemos que o clube não se opõe a escola ou a outros agentes aculturativos; apenas permite a renovação da nxperiência que a nova geração vai vivendo ao se afastar cada vez mais da família.

Criar um núcleo de convivência de "nissei" da mesma idade, necessàriamente não leva a afastá-los de contactos mais amplos. Os individuos de maior prestígio nos clubes são os que obtiveram êxito fora da colonia e cue são capazes de viver entre brasileiros fàcilmente. Entre os adolescentes que não freqüentam êsses núcleos, percebemos uma ligação muito 
mais intensa com a familia e uma submissão maior aos pais. Em tais condições, a escola não pode atuar eficiente e decisivamente como agente aculturativo, pois a sua ação se limita aos periodos de aula, e mesmo a comunicação entre os alunos é restrita. Não há condições para que as crianças ou os jovens renovem suas atitudes a partir dos contactos esporádicos que a escola brasileira impóe.

Evidentemente, não se pretende negar o papel desempenhado pela escola na aculturação dos "nissei". Basta lembrar a exigência do uso continuo e fluente do português, para que não se esqueça sua importância, mas a ação que ela exerce é paralela à de outras instituições e situações em que vivo o adolescente, e que vão exigir do jovem uma definição de atitude. E' ar que emerge neste a consciência de sua posirão marginal e tntão o "nissei" reage, como vimos, desenvolvendo maior lealdade à colória, mas ao mesmo tempo dispondo-se a renovar suas atitudes e lutar por єsta renovação. E' quando começa o papel da associação, que no momento ainda permite esta segregação, mas que provàvelmente, pelo desenvolvimento coerente que se impõe, no futuro irá abrir suas portas a jovens de outras origens, tal como aconteceu com clubes recreativos fundados por cutros imigrantes no passado. Isto talvez aconteça mais ràpidamente com os japonêses, de vez que a sua aculturação é rápida, pelo tempo que estão no Brasil, graças a certas condições especiais que atrás discutimos, e porque no interior do grupo nipo-brasileiro já começam a surgir defensores ardorosos da dissolução dos núcleos de segregação.

\section{NOTAS}

1) Indicamos, a título de exemplo: Antônio Xavier de Oliveira, "Três heróis da campanha anti-nipônica no Brasil: Felix Pacheco, Artur Neiva e Miguel Couto", Revista de Imigração e Colonização, ano VI, n. ${ }^{\circ}$ S 2-3, Conselho de Imigração e Colonização, Rio de Janeiro, 1945.

2) Censo Demográfico (1.0 de julho de 1950), Estados Unidos do Brasil - Seleção dos principais dados, Rio de Janeiro, IBGE, 1953 - pág. 5, quadro 5 .

3) Ibidem, pág. 26, quadro 15.

4) Saito, Hiroshi, "Tipologia do nissei", Jornal Paulista, 1-1-57.

5) Ibidem.

6) "Palavras de Inauguração", Jornal Paulista, 1.0 de Janeiro de 1947, 1. ${ }^{\circ}$ número, página japonêsa.

7) Alguns entrevistados foram bastante claros quanto a isto, afirmando: "Não há oposição dos pais quanto à freqüência a clubes, mas o que atrapalha são os estudos", ou "meus pais desejam que eu vá ao clube. mas os estudos não dão tempo", ou, ainda, "minha mãe gostaria de que eu freqüentasse; às vêzes vou a bailes". 
8) O nosso projeto de pesquisa assim apresentava o problema.

9) Podemos indicar algumas situações em que os "nissei" pretendem distinguir-se dos jovens ocidentais: 1) Uma "nissei" convidada por um amigo, também "nissei", para assistir a uma ópera moderna responde: "Isto não é coisa para nissei". 2) Um universitário afirma: "Há paz de espírito em falar japonês. Gostaria de conversar certos assuntos nessa língua com meus filhos e minha espôsa". 3) "Para certas situações, a lingua japonêsa é mais fácil, diz um jovem estudante, não me sinto bem cumprimentando em português. Há muitos jovens que quando namoram falam japonês, mesmo não sabendo falar bem".

10) Saito, Hiroshi, artigo citado.

11) Stoetzel, Jean, Jeunesse sans chrysanthème ni sabre, Plon, Unesco, 1954, pág. 75 .

12) Eisenstadt, S. M., From generation to generation. Age groups and social structure, Routledge and Kegan Paul, Londres, 1956.

(13) O Arelux, Órgão da Arelux, Associação Recreativa e Esportiva Lux, setembro de 1957, São Paulo, n. ${ }^{\circ} 1$, ano $1 .^{\circ}$.

(14) Alguns trechos de entrevistas com dirigentes de associações são especialmente significativos: 1) "Para os elementos que vêm do interior, o clube é intermediário. O 'nissei' é tímido e precisa de um ambiente para distrair-se, e quando não vai no clube, cai no snooker ou em outros caminhos ruins. Êsses clubes são intermediários, porque os do interior, aprendendo a dançar etc., podem participar de outros clubes brasileiros". 2) "A finalidade maior do clube é ensinar boas maneiras aos que vêm do sítio, para que possam entrar para outros clubes. Serve como um trampolim, ensinando a dançar, a conversar melhor, porque na roça não fazem ambiente com os brasileiros".

15) "Fatos e idéias", Jornal Paulista, 9-5-1953.

16) Quando iniciaram o Torneio Nipo-Brasileiro de Futebol, em que tomam parte tôdas as associações de São Paulo e algumas de fora, foi formalmente discutida a participação de elementos não "nissei", mas decidiram os representantes dos clubes pela não participação, alegando que os brasileiros jogam melhor que os "nissei", o que deixaria os últimos em situação de "inferioridade".

17) Relatório da VII caravana cultural, Associação Cultural e Esportiva Piratininga, julho de 1954 ( $\mathrm{ms}$ ).

18) "Impressão de viagem à Alta Paulista e Alta Sorocabana", Os Jovens, 25-2-57, São Paulo, ano 2, n. ${ }^{\circ} 11$, pág. em português.

\section{9) Ibidern.}

20) O trecho de entrevista transcrito na página anterior parece estar em contradição com esta afirmação, mas na verdade declara apenas a mudança de atitude do entrevistado com relação a sua familia. Teòricamente também êle admite o casamento misto, como qualquer outro membro da associação a que pertence. Isto mostra o papel dêstes grupos de jovens na homogenização da opinião. 
21) Em todos os relatórios de caravanas culturais encontramos o casamento misto como tema de discussão assim como no temário de tôdas as mesas-redondas de que participamos em diferentes "clubes".

22) Esta posição dos "issei" aparece claramente em um trecho do "Relatório da IX Caravana", 1955, Revista da Caravana, pág. 51: "...um dos caravanistas quis saber a opinião dos "issei" sôbre o baile. Para alguns senhores ali presentes, a dança não passa de um instrumento, um meio para arranjar casamento. Houve muitos protestos por parte dos caravanistas que procuravam dar maior ênfase à dança como recreação sadia e natural (congraçamento social). Para demonstrar o que foi dito, citaram o caso de pessoas casadas que também apreciam os bailes. Entre os ocidentais, nas festas familiares, é muito freqüente os casais trocarem de par. Isto tudo é muito natural, desde que não se interprete com malicia, pois alguns senhores não acataram bem êsse costume ocidental de troca de pares. Procuramos frisar também que os bailes (quando bem freqüentados, é claro) dão ainda oportunidades de fazer boas amizades e fazer trocas de idéias, não apenas entre pessoas de sexo oposto, mas também entre pessoas do mesmo sexo. Ainda não muito satisfeito com os nossos argumentos, um dos ouvintes formulou uma pergunta especial às moças da caravana: 'A moça não pensa imediatamente em casar-se com o rapaz que a convidou para dançar uma música?' Uma das caravanistas respondeu, dizendo que hoje em dia dificilmente encontraríamos uma jovem tão ingênua, capaz de pensamentos tão absurdos... (mas) reconhecem que os 'issei' devem procurar adaptar-se aos novos costumes e devem dar maior compreensão ao espírito dos 'nissei'". 